\title{
Innovation dynamics in the Brazilian industrial sector: scenario and reflexions
}

\author{
Claudia Brito Silva Cirani \\ Graduate Program of Business Administration, \\ Universidade Nove de Julho, Sao Paulo, Brazil \\ José Jaconias da Silva \\ Department of Administration, Universidade Federal de Mato Grosso, \\ Cuiabá, Brazil \\ Adalberto Ramos Cassia \\ Informatics and Knowledge Management Post-Graduation Program, \\ Universidade Nove de Julho, Sao Paulo, Brazil, and \\ Samara de Carvalho Pedro \\ Graduate Program of Business Administration, \\ Universidade Nove de Julho, Sao Paulo, Brazil
}

\begin{abstract}
Purpose - This study aims to analyze the innovation overview of the Brazilian industrial sector using data published by innovation survey - PINTEC. The aim was to provide a macro and updated diagnosis of the innovation scenario in Brazil and build reflections for further studies.

Design/methodology/approach - The authors used information from the years 1998-2014 covered by PINTEC to analyze innovation indicators, namely, innovation types, problems and obstacles, novelty degree, established partnerships and interactions, as well as governmental incentives. This study is exploratory; thus, descriptive methods were used for data presentation through analyses and presented through figures and tables.

Findings - The results show that innovation of the Brazilian industrial sector is concentrated mainly in the acquisition of machinery and equipment, innovations that already exist in national or global markets, interactions for the innovation process with suppliers and governmental support for financing machinery and equipment acquisitions.
\end{abstract}

Originality/value - This study has relevance, as its results provide important subsidies for policy-makers to incorporate the needs and overcome challenges of innovation in Brazil.

Keywords Innovation, Brazil, Industrial sector, PINTEC

Paper type Research paper

(c) Claudia Brito Silva Cirani, José Jaconias da Silva, Adalberto Ramos Cassia and Samara de carvalho Pedro. Published in Innovation and Management Review. Published by Emerald Publishing Limited. This article is published under the Creative Commons Attribution (CC BY 4.0) licence. Anyone may reproduce, distribute, translate and create derivative works of this article (for both commercial and non-commercial purposes), subject to full attribution to the original publication and authors. The full terms of this licence may be seen at http://creativecommons.org/licences/by/4.0/legalcode

Innovation dynamics

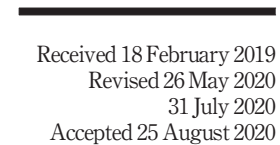

Accepted 25 August 2020

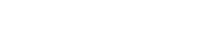


INMR

18,2

\section{Introduction}

According to the neo-Schumpeterian approach (Ahuja, Lampert, \& Tandon, 2008), innovation in emerging economies is a multi-level process based on a broader understanding. Essentially, innovation means a structural change in various dimensions: technological, industrial, organizational. Several criteria are also involved in the innovation process, such as internal structure (Filippetti \& Archibugi, 2011), creativity (Martins \& Terblanche, 2003), trades in the international market and company investments (Abernathy \& Utterback, 1978; Jägle, 1999), as well as local strategies adopted by the country, enterprises and governments (Radosevic \& Yoruk, 2016).

These strategies contribute to the innovation process differently in emerging economies (Wang, Fu, \& Chen, 2014). They mean not only investments in research and development (R\&D), but also improvements in the production capacity, engineering development and new forms of governmental support or new business models. Thus, there is a need to better understand innovation in emerging economies.

Brazil displays an interesting context for studying variables of innovation-related performance as the country stands out in the Latin American region because of its highly globalized and diversified economy. Furthermore, Brazilian economic and social structures differ from scenarios in developed countries. The peculiar characteristics of innovation processes in Brazil allow the analyses of its innovation system and provide researchers and policy makers subsides to encourage awareness and use the results of surveys on innovation.

The study is based mostly on the PINTEC, a survey on innovation that follows the guidelines established by the Oslo Manual, published by the Organization for Economic Cooperation and Development (OECD, 2005). The Oslo Manual is a reference for developing research on innovation. Since its first publication, in 1992, there have been efforts of communities, such as Eurostat and OECD (through the Community Innovation Survey), to disseminate the standards to European countries and other countries worldwide. The OECD studies are consistently used to guide policy decisions (Christensen, Rogaczewska, \& Vinding, 1999; OECD, 1999).

In Brazil, the OECD methodology was adopted by the Brazilian Institute of Geography and Statistics - IBGE - from the publication of the first PINTEC survey for the year 2000. The survey was repeated in 2003, 2005, 2008, 2011 and 2014. Today, the PINTEC is the main source for analysis of national innovation systems (NIS), whose most important definitions are described in Lundvall (2016), Freeman and Soete (1997) and Nelson (1993).

In this study, data from all PINTEC editions were analyzed to provide a macro and updated diagnosis of innovation overview of the Brazilian industrial sector, which accounts for $90 \%$ of innovative companies identified by the PINTEC survey. In addition, this study seeks to raise questions to be investigated in future studies.

This study was conducted considering the Brazilian context, and its analysis generates knowledge that may be relevant not only for strategic decision-making processes, but also for new policies, for monitoring results of policies already established and for guiding the private sector. In addition to investigating the macro level of innovation in Brazil, this study provides subsidies to public policies of incentive and, consequently, to the development of new business strategies for innovation.

This study aims to raise general questions to guide in-depth research on relevant issues, under different dimensions, such as the size of Brazilian industrial companies, the nature and intensity of innovation types, the novelty degree of changes implemented, partnerships and interactions established and the profile of access to instruments to encourage innovation. This work shows relevance, as its results could be used as important subsidies 
for the creation of public policies to meet the needs and tackle the challenges of innovation in Brazil.

\section{Theoretical framework}

Innovation drives economic development through a dynamic process, called creative destruction, in which radical innovations generate drastic breaks, while incremental innovations change processes continuously (Schumpeter, 1934).

Both concepts of innovations are properly certified and referenced in literature. Their importance is also observed by the central role they represent for the current technological development, evidenced by the increase of research and the emergence of start-ups (Bicen \& Johnson, 2015). Although it is not a new science, which often requires substantial changes in products and processes, incremental innovations present significant results to businesses (Hollander, 1965; Henderson \& Clark, 2009), namely, risk reduction in portfolios of investments (Leifer, McDermott, O'connor, Peters, Rice, \& Veryzer, 2000; Min, Kalwani, \& Robinson, 2006). On the other hand, radical innovation could be defined as innovation with a significant impact on a market and on the economic activity of the enterprise (Cooper \& Schendel, 1976; OECD, 2005).

Innovation, whether incremental or radical, confers competitive advantages for companies (OECD, 2005). Thus, researchers have sought to understand how to strengthen the capacity of companies to innovate to provide competitiveness and a better financial performance to businesses (Henderson \& Clark, 1990).

The concept of innovation capacity could be understood as the ability of employees to mobilize knowledge in combination with their technical skills and other knowledges, resulting in new products or processes (Kogut \& Zander, 1992). This concept arises from the theory of resource-based view - RBV, which proposes that resources are strategic for a competitive advantage (Barney, 1991). The RBV has a theoretical framework that identifies which features and capacities have potential to generate competitive advantage to the company. Companies that successfully assess features and capacities have improved their market performance (Wernerfelt, 1984).

Therefore, resources are crucial for companies seeking to achieve a long-term competitive advantage (Barney, 1991). In addition, innovation in enterprises consists of both internal and external resources (Swink, 2006). Thus, a new approach complements the RBV - dynamic capacity theory (Teece, Pisano, \& Shuen, 1997) - which proposes that not only specific features and capacities of a company generate a competitive advantage, but also the processes of learning, coordinating and restructuring resources within and outside the company (Teece et al., 1997).

Data collection on business capabilities for innovation is of utmost importance for the analysis of innovation factors and impacts (why some companies innovate and others do not), types of innovation activities carried out by companies as well as their impacts (OECD, 2018). Broadly speaking, Lawson and Samson (2001) propose that innovation capacity refers to the capability of continuously transforming ideas and knowledge into new products, processes and organization systems into utilities for customers, as well as the capacity of properly managing internal resources to generate innovation while acquiring knowledge and skills to operate in the market. The capacity of a company to generate innovation determines productivity, increasing product quality, developing new products or processes (Wade, 2012), and thus determining the capacity of enterprises to compete in other economies, especially in developed countries.

Literature on technological changes reports differences between the trajectory of developed countries and emerging countries (Lander \& Thorsteinsdóttir, 2011). In emerging 
INMR

18,2

countries, the models indicate that many technologies, in general, were initially acquired from developed countries and then assimilated and adapted, generating learning from this customization process. In addition, emerging economies have experienced scientific and technological overflows for technologically promising sectors, such as biotechnology (Ramamurti, 2012; Kiss, Danis, \& Cavusgil, 2012).

In the past decade, the development of emerging economies as drivers of global economic growth has been one of the most crucial trends. Emerging economies increasingly represent world exports, including technology, while companies from emerging countries have increased their profile in the global innovation scenario (Altenburg, Schmitz, \& Stamms, 2008; Ernst, 2008; Li \& Kozhekode, 2009; Lema, Quadros, \& Schmitz, 2015). These changes require the construction of technological structures to move from basic to advanced innovation capabilities.

The literature has contributed to building a consensus about the role of innovation in the upgrading and leapfrogging processes of technology for emerging economies (Fu, Pietrobelli, \& Soete, 2011; Lee, 2013; Primi, 2014). Evolutionary approaches (Neson \& Winter, 1982) support innovation as a path-dependent process whereby knowledge and technology are developed through interaction between multiple agents and factors. Some researchers have proposed a leapfrog method, either by using a window for technological development or by creating a new path (Perrez \& Soete, 1988; Lee \& Lim, 2001). Others have supported an incremental path by importing technology to create original R\&D (Kim, 1997). New economic structures indicate that the path to technology upgrade, as based on "copying industries" using latent comparative advantages, is crucial in the transition from low to middle-income levels (Lin, 2012).

Brazil holds an intermediate position, a middle-income country, where even technology upgrade seems difficult to achieve. However, technological paths, already known and used by leading countries (Primi, 2014), are in its favor. Brazil has a private endowment of factors, which gives the country a competitive advantage in some sectors, such as tropical lowcarbon farming, offshore oil exploration and production of small and medium-sized aircrafts (Castro, 2015). Thus, in some segments of the technology frontier, which provide institutional advantage and competitiveness in the international market, Brazil may be capable of not only keeping update technologically, but also leapfrogging leading countries. For example, the production of mid-sized jet planes by Embraer (Brazilian Aircraft Company) that shifted a scenario of crisis to a growth opportunity by taking up market niches in international region aviation and enterprises in the market of low-cost jets (Lima, Migon, \& Gomes, 2009). However, many industrial chains do not attain international competitiveness. Although they adopt international standards by absorbing technologies generated abroad (copying industries) (Lin, 2012), these enterprises have features to the domestic market. Brazilian institutions are national and local with peculiarities that do not comply with importation of products and processes (Castro, 2015).

Regarding the innovation system of the Brazilian industry, three inter-related aspects need to be improved. First, transformation of business clusters (production clusters) into dynamic and innovative groups. Second, creation of a new productive system. Third, guarantee of macroeconomic conditions that ensure support and sustainability for enterprises to improve their productive and innovative capacity (Cassiolato, Lastres, \& Maciel, 2003). Therefore, the adoption of a strategic program for innovation in missionoriented areas with high amounts of strategic natural resources, such as energy, environment and agribusiness, could improve the current innovation system and help generate inclusive and sustained growth (Mazzucato \& Penna, 2016). 


\section{Research method}

The data used in this study were obtained from the IBGE website. The analysis period refers to six editions of - PINTEC 2000 - for the triennial 1998-2000, PINTEC 2003 (triennial 2001-2003), PINTEC 2005 (triennium 2003-2005), PINTEC 2008 (triennium 20062008), PINTEC 2011 (triennium 2009-2011) and PINTEC 2014 (triennium 2012-2014). The study emphasizes the PINTEC survey 2012-2014, the most recent edition (IBGE, 2016).

The methodological line used is descriptive, and we carried out an exploratory analysis of the data, assessed and presented in figures and tables to investigate the key innovation indicators extracted from tabulations of all PINTEC editions, namely, innovation types, obstacles to innovation, novelty degree, innovative activities, cooperation and incentives, providing a general and updated overview of innovation in Brazil. The descriptive analyses allow checking the behavior of indicators using quantitative data, which is crucial for an exploratory analysis that can evolve to testing theories (Contandriopoulos, Champagne, Potvin, Denis, \& Boyle, 1997). The methodological procedures below were used to ensure quality of the analyses.

The first step of the research consisted of organizing the PINTEC survey database. We separated each indicator (nature of innovations, problems and obstacles, novelty degree, innovative activities, cooperation, innovation incentives) by sector (extractive or manufacturing industrial sector) considering the Brazilian context. A systematic work was performed to build the database and prepare figures and tables. Finally, some reflections were made on the data to construct a framework of questions for further investigating in future studies. These questions are highlighted in the following section.

Although the focus of this work is the industrial sector, the PINTEC survey covers not only extractive and manufacturing activities of the industry, but also the power and gas sectors and some other selected services. The industrial sector was chosen for the study, as most innovative companies identified by the PINTEC survey are in the industrial sector, which accounts for $90 \%$ of the sample.

PINTEC adopts a methodology compatible to the Community Innovation Survey (CIS) carried out by the Statistical Office of the European Communities (Eurostat). Both surveys use the Oslo Manual as a methodological reference; therefore, innovation studies in Brazil generate results compatible to those obtained by European countries. The aim is to allow comparison as a reference and build a coherent international system of innovation. PINTEC and CIS are available at, respectively: www.PINTEC.ibge.gov.br/downloads/Questionario\% 20PINTEC \%202014.pdf and https:/circabc.europa.eu/faces/ssp/extension/wai/navigation/ container.jsp.

IBGE (Brazilian Institute of Geography and Statistics) conducts the PINTEC survey each three years and releases the data online at www.pintec.ibge.gov.br. The questions are made through telephone calls to all companies, where the person in charge of a determined sector is contacted to participate; however, some interviews are conducted in person. The IBGE guarantees credibility of the data informed, in compliance with Brazilian laws.

The interviews are based on a questionnaire previously sent to the enterprise. For this strategy to work properly and to ensure quality of the data collected, the professional in charge of providing the information is able to prepare him/herself in advance. Typical questions are: What is the nature of innovations? What is the profile of the innovative activities? How did interactions with other agents occur? What is the profile of the innovative activity in terms of size and sector? Has the enterprise used governmental programs for innovation incentive?

Moreover, this work focuses on innovation of products and processes. Innovation research follows recommendation of the Oslo Manual (OECD, 2005), with emphasis on the 
INMR

18,2

150

technological innovation, not by examining in detail the organizational and marketing innovation. In addition, although the PINTEC survey provides data about Brazil, in major regions and states of the country, the analysis occurred in the Brazilian context to consolidate the aggregate results for the entire country. The variables investigated in PINTEC survey are shown in Figure 1.

Figure 1 shows innovation indicators to be examined under the PINTEC survey data; however, for further examination of the results, a detailed analysis of the key indicators was prioritized and listed below (as defined in the Oslo Manual, 2005):

- Innovation profile considering company size (company characteristics)

For innovation surveys, company size is an important classification to understand innovation processes in emerging economies, and company size should be measured in terms of number of employees. As innovation processes, other than $R \& D$, are generally performed by micro and small-sized units, company size classes should include smaller companies (OECD, 2005). In this respect, the enterprise informs the number of people it employs.

- Problems and obstacles

Figure 1.

Measurement structure of innovation indicators of the PINTEC survey

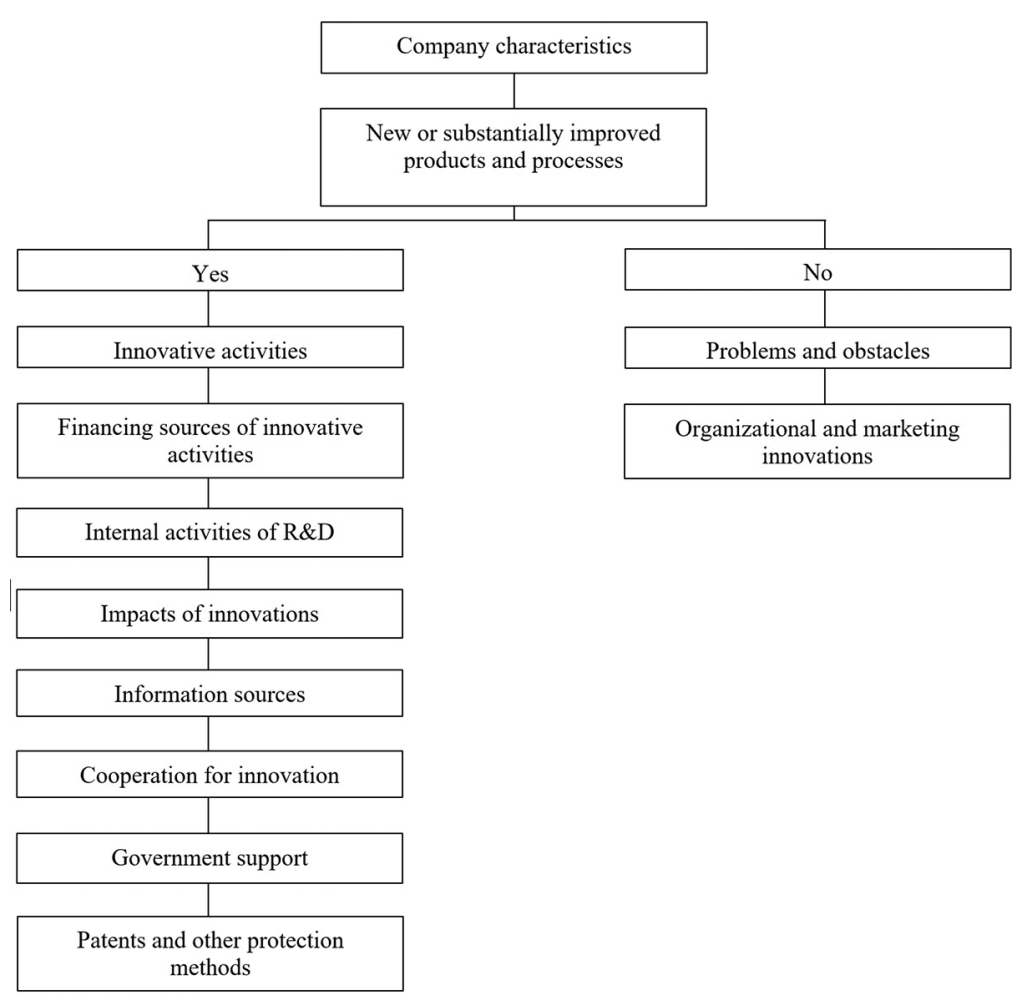

Source: IBGE (2016) 
The company informs difficulties or obstacles that slow down the process of implementing innovation. For the company that reported problems, a list of factors that may have affected their innovative activities is presented. The enterprise is then requested to inform the importance of each item: economic factors (costs, risks, funding sources), internal problems (organizational rigidity), technical deficiencies (lack of qualified suppliers, lack of qualified labor force), information problems (lack of information on technology and markets), problems regarding the national innovation system (scarce possibilities of cooperation with other companies and institutions), regulation problems (difficulty to comply with standards, rules and regulations).

- Type of innovation (if innovation occurred in the product or process)

According to the Oslo Manual, product innovation is the introduction of a product or service that differs significantly in their characteristics or intended uses from products previously produced by the enterprise. The innovation process is the implementation of a new or significantly improved method to create and provide services. The company informs whether the product or service or technologically new or significantly improved process was introduced to the market and briefly describes the main product or process introduced.

- Degree of novelty (whether the innovation is new to the world, to the market or to the company)

The company indicates the degree of novelty of the innovation implemented. The company informs if it is new to the company, but existing in the domestic market, or new to the domestic market, but existing in the world market, i.e. no company in the country produced that innovation with the same specifications, or new to the world market, meaning that no company in the world produced that innovation with the same specifications.

- Profile of innovative activities

The company points out the importance (high, medium, low and not developed) of efforts for improving its technological acquisition and, therefore, for the development and implementation of innovations developed by the company (machinery and equipment acquisitions, training, industrial project/technical preparations, internal R\&D, introduction of innovations to the market, acquisition of external knowledge, acquisition of external R\&D, software acquisition).

- Interactions with other agents, such as networks, university-enterprise cooperation, partnerships, etc. (cooperation for innovation)

The enterprise informs whether or not it participated in cooperation and mentions the main partner (university-research institution, consultants, professional improvement centers, conferences and publications, competitors, trade shows, suppliers, customers, information network).

- Access to instruments for innovation incentive (governmental support)

The company reports whether or not it used at least a governmental program to sponsor its innovative activities. If yes, it indicates which governmental program for innovative activities was used, e.g. financial support, R\&D financing in partnership with universities, fiscal incentives by informatics law, R\&D financing without partnership with universities, public purchases, R\&D fiscal incentive, financing machinery and equipment and other support programs.
Innovation dynamics 


\section{INMR}

18,2

\section{2}

Table 1.

Participation of industrial companies in the PINTEC survey of 2000, 2003, 2005, 2008, 2011 and 2014 , according to the size-Brazil

\section{Results}

Information presented in the innovation survey considers differences in terms of company size into three groups: micro and small, between 10 and 99 employees, medium from 100 to 499 employees and large enterprises with 500 or more employees.

The universe examined by the PINTEC survey is highly comprehensive: 132,529 companies, with at least ten employees between 2012 and 2014 related to the latest survey and comprised 117,976 innovative companies within the extractive and manufacturing industrial sectors, accounting for roughly $90 \%$ of the universe covered by the PINTEC survey of 2014.

The analysis of company size in Tables 1 to 3 shows that the sector of micro and small businesses is highly significant in the six editions of the PINTEC survey (2000, 2003, 2005, 2008, 2011 and 2014). The data show that in 2014, $91.3 \%$ of the companies in the industrial

\begin{tabular}{lrrrrrr}
\hline & \multicolumn{5}{c}{ Participation in the sample (\%) } \\
No. of employees & 2000 & 2003 & 2005 & 2008 & 2011 & 2014 \\
\hline From 10-29 & 65.4 & 65.4 & 65.4 & 64.2 & 64.9 & 66.3 \\
From 30-49 & 13.2 & 14.3 & 14.3 & 15.6 & 15.1 & 14.9 \\
From 50-99 & 10.5 & 10.9 & 10.9 & 11.0 & 11.2 & 10.1 \\
From 100-249 & 6.5 & 5.8 & 5.8 & 5.7 & 5.5 & 5.3 \\
From 250-499 & 2.5 & 2.0 & 2.0 & 1.9 & 1.6 & 1.8 \\
500 or more & 1.9 & 1.6 & 1.6 & 1.7 & 1.7 & 1.7
\end{tabular}

Source: IBGE $(2002,2005,2007,2010,2013,2016)$

\section{Table 2.}

Participation of industrial companies that innovated in the PINTEC survey of 2000, 2003, 2005, 2008, 2011 and 2014, according to the size-Brazil

\begin{tabular}{|c|c|c|c|c|c|c|}
\hline \multirow[b]{2}{*}{ No. of employees } & \multicolumn{6}{|c|}{ Participation in total companies that innovated $(\%)$} \\
\hline & 2000 & 2003 & 2005 & 2008 & 2011 & 2014 \\
\hline From $10-29$ & 52.5 & 59.8 & 59.8 & 62.1 & 62.1 & 57.6 \\
\hline From $30-49$ & 14.0 & 14.7 & 14.7 & 14.4 & 14.0 & 16.9 \\
\hline From 50-99 & 14.3 & 11.4 & 11.4 & 11.6 & 12.2 & 12.5 \\
\hline From 100-249 & 10.1 & 7.6 & 7.6 & 6.4 & 6.7 & 7.3 \\
\hline From 250-499 & 4.6 & 2.9 & 2.9 & 2.4 & 2.4 & 2.7 \\
\hline 500 or more & 4.5 & 3.5 & 3.5 & 3.1 & 2.6 & 3.0 \\
\hline
\end{tabular}

Source: IBGE (2002, 2005, 2007, 2010, 2013, 2016)

\section{Table 3.}

Participation of industrial companies that innovated in the PINTEC survey of 2000, 2003, 2005, 2008, 2011 and 2014, according to the size-Brazil

\begin{tabular}{lcccccr}
\hline & \multicolumn{5}{c}{ Companies that innovated } \\
No. of employees & 2000 & 2003 & 2005 & 2008 & 2011 & 2014 \\
\hline From 10-29 & 25.3 & 30.4 & 30.4 & 36.9 & 34.0 & 31.6 \\
From 30-49 & 33.3 & 34.2 & 34.2 & 35.2 & 33.1 & 41.2 \\
From 50-99 & 43.0 & 34.9 & 34.9 & 40.1 & 38.6 & 45.4 \\
From 100-249 & 49.3 & 43.8 & 43.8 & 43.0 & 43.4 & 50.8 \\
From 250-499 & 56.8 & 48.0 & 48.0 & 48.8 & 52.3 & 55.7 \\
500 or more & 75.6 & 72.6 & 72.6 & 71.9 & 55.9 & 65.7 \\
Source: IBGE (2002, 2005, 2007, 2010, 2013, 2016) & & & & \\
\hline
\end{tabular}


sector were considered small, with less than 100 employees; $7.1 \%$ medium-sized, with 100 499 employees; and 1.7\% large enterprises, i.e. $87 \%$ of innovative enterprises are micro and small enterprises with 10-99 employees. Larger companies tend to innovate more; however, as few Brazilian companies are characterized as large; small businesses have a greater representation in the results.

Data of six PINTEC surveys have shown as the main obstacles and difficulties faced by businesses, in descending order of importance: high costs for innovating, lack of appropriate funding sources and high economic risks. All factors are economic in nature and remained the same in all editions of the survey. Micro and small companies lack capital to drive innovation projects and thus face more difficulties to obtain external financing than larger enterprises do (OECD, 2005). Thus, the question is: regarding company size, as the sector of micro and small enterprises is highly significant (Tables 1 to 3 data), should not small businesses face less difficulty to access financing support than larger enterprises do?

Figure 2 presents the percentage of innovative companies according to the innovation introduced: product innovation and process innovation. In the Brazilian industrial sector for the six PINTEC surveys, most companies implemented only innovation, whose concept is more related to production and distribution methods to reduce costs (OECD, 2005) than generating knowledge per se, which are generally patent drivers. Therefore, the predominant content of innovations in Brazil is based on efforts to update and modernize technology.

There are interesting differences in the main innovation drivers between these two types of innovations. According to the data collected in the 2014 PINTEC survey on product innovations, $78 \%$ has internal efforts of the company as the main driving force for innovation. In process innovations, however, $66 \%$ has other companies or institutes as the main driver. Therefore, process innovations have a greater dependence on external sources, compared with product innovations. The challenge the company capacities in developing countries to overcome technology-related problems leads companies to solutions which, for the most part, rely on the knowledge acquired externally from various channels, such as other companies or institutes (purchase of new technology incorporated into machinery and equipment) (OECD, 2005). Although it cannot be proven, dependence on external sources of

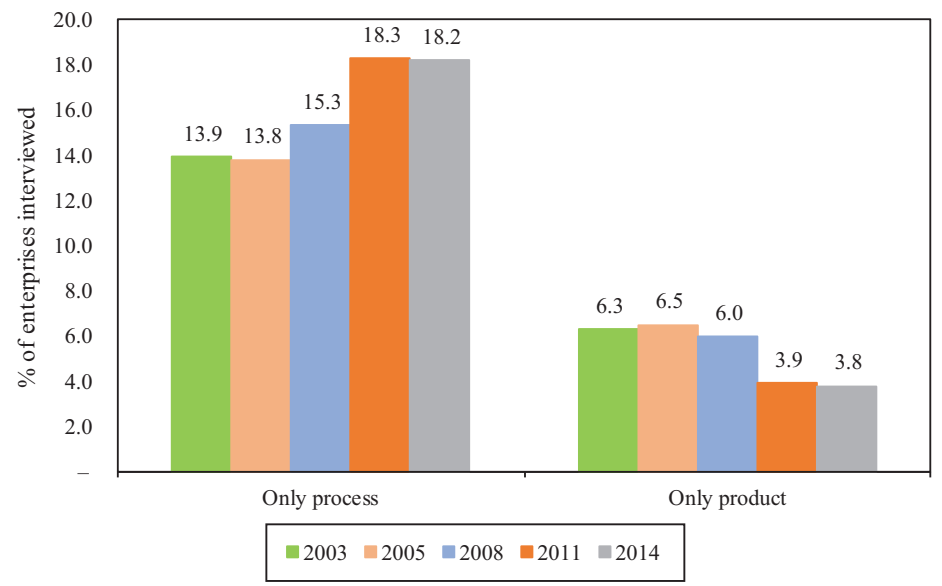

Source: IBGE (2002, 2005, 2007, 2010, 2013, 2016)
Innovation dynamics

153
Figure 2.

Percentage of industrial companies, according to innovation types Brazil 
INMR

18,2

154

technological knowledge can be related to the fact that many innovations implemented in Brazil consist of acquiring technological knowledge embedded in machinery and equipment, as further explained.

Data presented in Figure 2 show that process innovations account for most innovations in Brazil. According to OECD (2005), peculiar characteristics of the economy in many developing countries influence innovation in many ways; therefore, understanding innovation in these countries requires learning about their production structure. According to OECD (2005), in most developing countries, competitiveness is based mainly on the exploration of natural resources. Brazil has vast strategic natural resources (Mazzucato \& Penna, 2016). In production or in the Brazilian foreign trade, the presence of products requiring intensive use of agricultural and mineral resources is increasing (Castro, 2015). Therefore, the question is: can the Brazilian productive structure, characterized by the presence of agricultural products and minerals, lead companies to innovate more in processing than in the product?

By definition, all innovations should contain some novelty degree: new to the world, new to the market and new to the company, i.e. the concept of innovation also covers what is new only from the perspective of the company itself (OECD, 2005). For a detailed analysis of this indicator and in view of the restriction in physical space to address every year in the same table without compromising the quality of the illustration, we decided to analyze only the data of the last PINTEC survey (2014); however, percentage values were similar to those observed in previous surveys. Table 4 presents the novelty degree associated to innovation type for the 2014 PINTEC survey. The data show that the product represents a novelty to the world market in $2 \%$ of the cases; to the domestic market, in $19 \%$, i.e. $79 \%$ of the industrial companies indicated that their main product represents a novelty only for themselves. The data are even more significant in terms of process in which innovation was novelty to the world market in $1 \%$ of the cases; to the national market, $8 \%$; and for $91 \%$ of the companies, process meant a novelty just for themselves.

Table 4 also shows that the percentage of enterprises that implemented process innovations $(38,534)$ is $80 \%$ greater than the number of companies that implemented product innovation $(21,557)$, corroborating the results found previously (Figure 2). Even more serious is the fact that the Brazilian industrial sector shows more facility in process innovation, but this innovation type has more difficulties to achieve a higher novelty degree.

Table 4.

Brazilian industrial sector: novelty degree of product/ process innovation percentage of enterprises

\begin{tabular}{|c|c|c|c|c|}
\hline Novelty degree & $\begin{array}{c}\text { Total } \\
\text { innovative } \\
\text { companies }\end{array}$ & $\begin{array}{l}\text { innovation } \\
\text { Novelty degree of } \\
\text { product } \\
\text { innovations in } \\
\text { companies that } \\
\text { implemented } \\
\text { innovations }(\%)\end{array}$ & $\begin{array}{c}\text { Total } \\
\text { innovative } \\
\text { companies }\end{array}$ & $\begin{array}{l}\text { innovation } \\
\text { Novelty degree of } \\
\text { process } \\
\text { innovations in } \\
\text { companies that } \\
\text { implemented } \\
\text { innovations }(\%)\end{array}$ \\
\hline Total & 21,557 & 100 & 38,534 & 100 \\
\hline $\begin{array}{l}\text { Novelty to the company, but } \\
\text { existing in the national market }\end{array}$ & 17,000 & 79 & 35,134 & 91 \\
\hline $\begin{array}{l}\text { New to the domestic market, but } \\
\text { existing in the world market }\end{array}$ & 4,064 & 19 & 3,097 & 8 \\
\hline New to the world market & 493 & 2 & 302 & 1 \\
\hline
\end{tabular}


This means that 302 companies reported process innovation with novelty degree to the industrial sector worldwide, while 493 Brazilian enterprises presented product innovations to global industrial sector.

A concept related to novelty degree is radical innovation. This innovation causes a significant impact on a market and economic activity of enterprises (Schumpeter, 1934; Tushman \& Anderson, 1986). This concept is centered on innovation impact, as opposed to its novelty degree. For example, the impact could change the market structure, create new markets or make existing products obsolete (OECD, 2005). When the product or process is new to the world market, we refer to "state of the art." Thus, not all radical innovation is necessarily new to the world market. The opposite, however, is not true, meaning that a new product or process to the world market may refer to increased innovation in existing products or processes.

The Brazilian industrial sector could be characterized particularly by larger relative presence of process innovation (Figure 2). In addition, the data collected in this study show that innovation does not contribute to a better participation of Brazil in the international market, as innovation to the company itself predominates in the country; nevertheless, it is not novelty to the national or world markets (Table 4). Therefore, the following reflection was drawn from data presented in Table 4 and could support future studies: although the Brazilian industrial sector is more resourceful in process innovation (more innovation of process), why does this type of innovation (not in product) have more difficulties to achieve a higher degree of novelty (new to world market)?

Another innovation indicator investigated by the PINTEC survey refers to innovative activities that seek to evaluate qualitatively the frequency and degree of importance - high, medium, low or not relevant - of innovation categories of companies. For example, internal and external acquisition of R\&D and other knowledges, purchases of software, machinery and equipment, training, introduction of technological innovations into the market and industrial project and other preparation techniques (OECD, 2005; IBGE, 2016) to make their innovations viable.

Figure 3 shows that six PINTEC surveys (2000, 2003, 2005, 2008, 2011 and 2014) present a similar behavior in terms of innovation activities. The Brazilian industrial sector provides innovations based on the access to technological knowledge through acquisition of machinery and equipment. Using the 2014 PINTEC survey as reference, acquisition of machinery and equipment continues to be the most relevant form of innovation for the industrial sector $(73.8 \%)$, followed by training $(61.7 \%)$ and software acquisition $(31.7 \%)$. This result shows that innovation in most Brazilian companies involves, above all, modernization of their processes through machinery and equipment acquisition, rather than investments in R\&D (only $15.2 \%$ of companies stated high importance for internal R\&D).

The results of the 2014 PINTEC survey showed that investments in innovation point to the same path. Investments of enterprises in innovation for machinery and equipment acquisition account for $41 \%$ of the total, while only $30 \%$ is allocated for internal R\&D activities.

Acquisition of machinery and equipment is associated to changes in the production process to reduce costs, while $R \& D$ efforts are related to improvement or generation of new products, namely, development of "the state of the art." Therefore, Brazilian enterprises give importance to innovation activities that are less likely to generate new products.

Acquisition of technology incorporated (purchase of machinery and equipment) for innovation is characteristic of developing countries (OECD, 2005). Technological strategy characteristic of emerging economies is concentrated on technology importation (Kim, 1997), which is incorporated into the state-of-the-art machinery and equipment. It may indicate 


\section{INMR}

18,2

156

Figure 3.

Innovative activities considered of high importance for industrial companies that innovated $(\%$ of responses) - Brazil

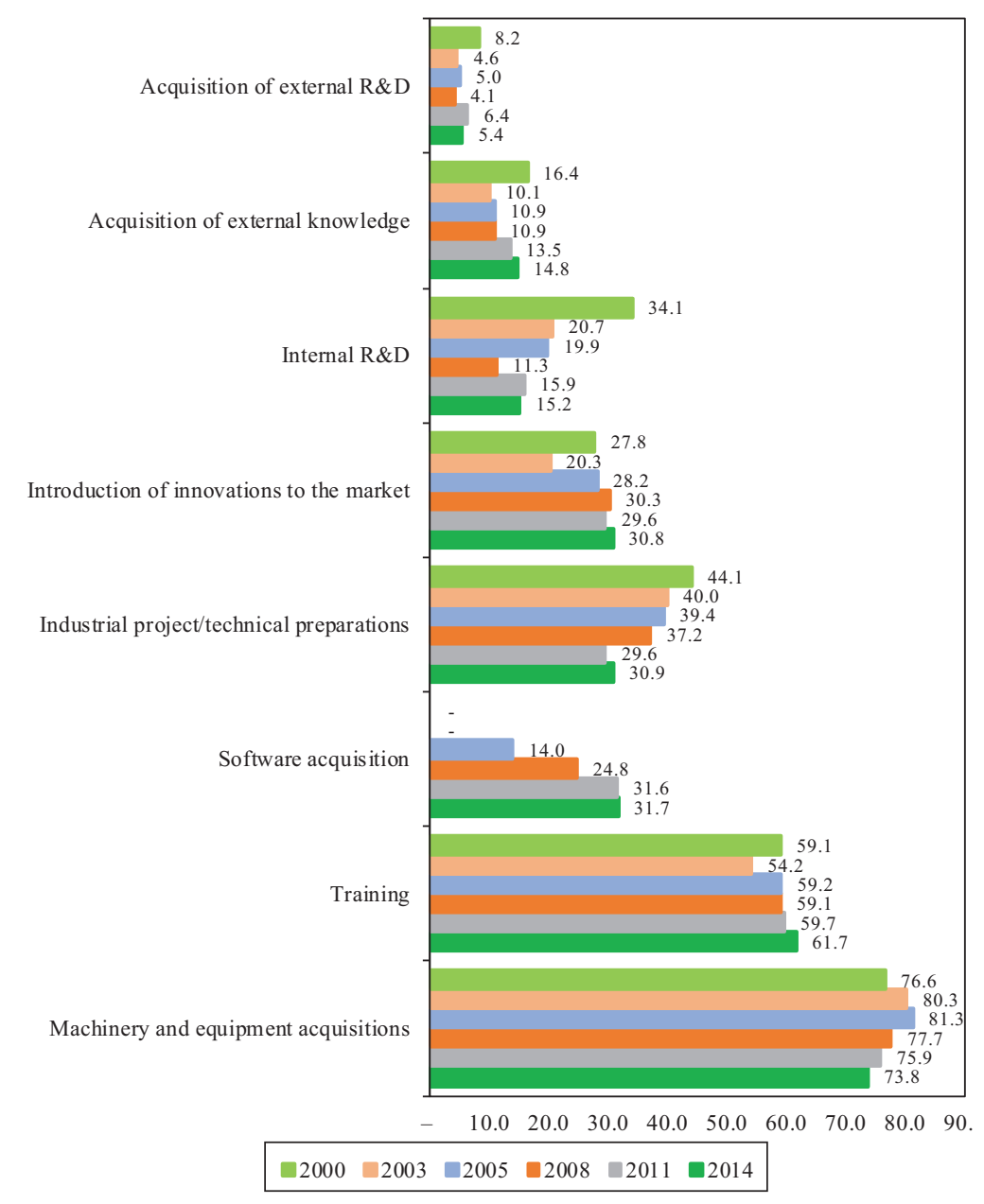

Source: IBGE (2002, 2005, 2007, 2010, 2013, 2016)

that little is done to develop the knowledge necessary for effective development (Teece et al., 1997). The technology upgrade based on using industrial innovation develops abroad seems prevail among developing countries (Lin, 2012). Based on this discussion and on PINTEC survey data presented in this study, a careful consideration for future studies arises: can the technological change of the Brazilian industrial sector be characterized as predominantly by the adoption and improvement of innovations generated in foreign countries?

Sharing knowledge between companies and other actors is essential to strengthen the capacity of companies to generate innovations (OECD, 2005). Therefore, to innovate, businesses need to establish interactions among their staff members to analyze, interpret and innovate internally and with stakeholders to identify opportunities to share knowledge (Henderson \& Clark, 1990) and establish inter-organizational relations for innovation processes. 
Figure 4 shows how interactions with other actors of the Brazilian NIS occur in six PINTEC surveys (2000 PINTEC, 2003 PINTEC, 2005 PINTEC, 2008 INTEC, 2011 PINTEC, and 2014 PINTEC). The data show that partnerships identified as the most important were with suppliers, customers and consultants, in descending order. On the other hand, interactions with competitors and universities and research institutions are regarded as low importance. This result should be a source of concern, as universities and research institutes tend to become more involved in R\&D activities, depending on the sector.

Innovation in Brazilian companies occurs for specific improvements of production processes and involves acquisition of machinery and equipment rather than improvement of R\&D or original activities for the development of novelties. This is supported by the closer interaction of enterprises with partners in their production chains, i.e. suppliers, customers, buyers or consumers.

Interactions in the innovation process could overcome the lack of internal resources, considered as strategic sources for competitive advantages, according to the theory of RBV (Barney, 1991), promoting thus information on exchange, resource acquisitions, technology

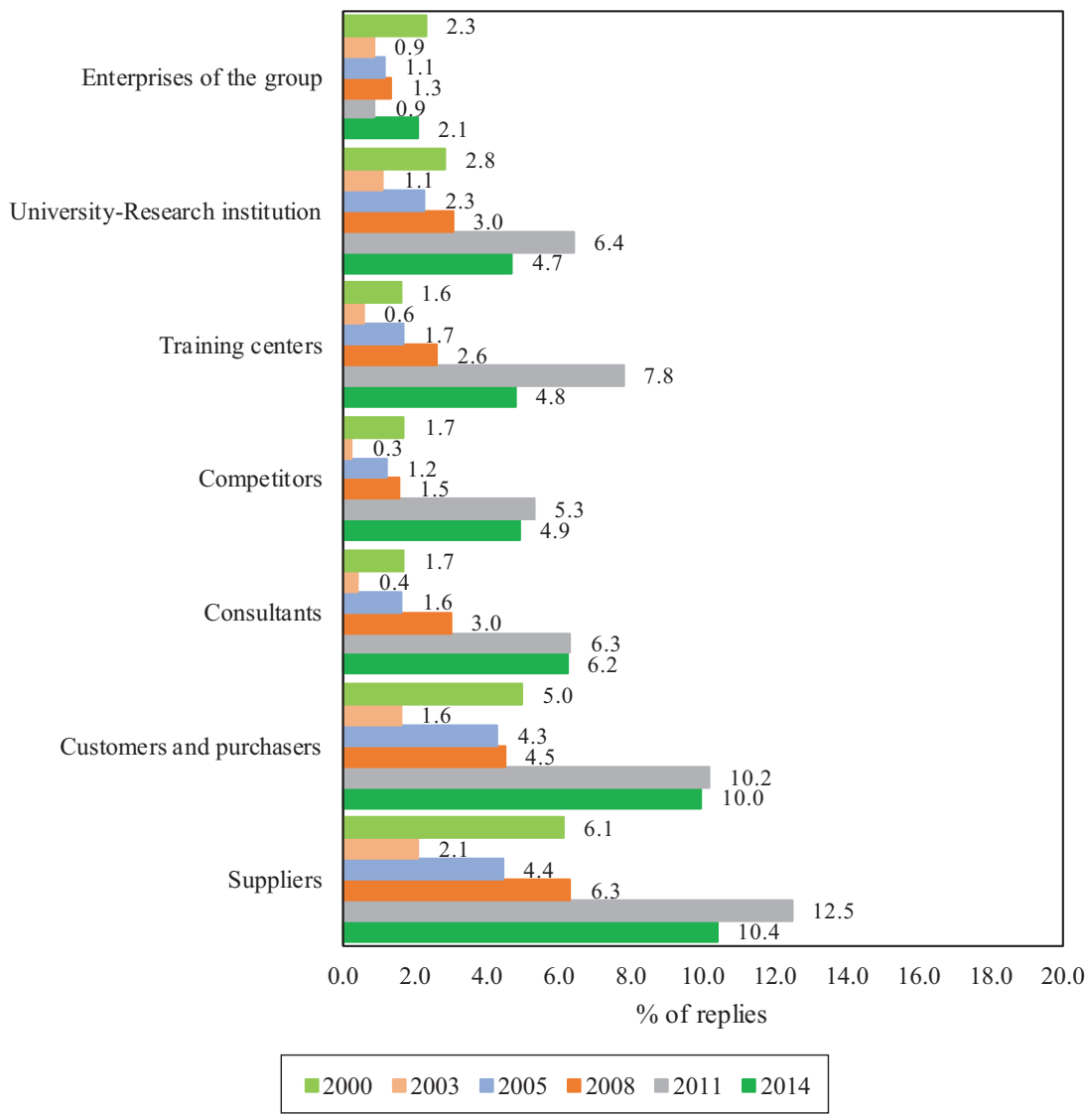

Source: IBGE (2002, 2005, 2007, 2010, 2013, 2016)

Figure 4. Most frequent partners for interaction, according to the industrial companies that innovated (ranked by the number of responses)-Brazil 
INMR

18,2

\section{8}

Figure 5.

Percentage of enterprises that have implemented innovation with and without governmental support-Brazil transfer and risk management. Networks, as well as cooperation agreements for innovation, are considered alternatives to fill the gap of human, financial and management resources, providing innovation capacities that could not be reached otherwise (Zucoloto \& Nogueira, 2016). In relation to the innovation system of the Brazilian industrial sector, the production design is one of the main aspects that still needs to be improved. It is necessary to change the production clusters and the interactions between companies into more dynamic and innovative groups (Cassiolato et al., 2003).

Therefore, in Brazil, the federal government changed the focus of policies on the interaction of universities and research institutions in 2005, when the Innovation Law (Law $\left.\mathrm{N}^{\circ} 10.973,2004\right)$ was enacted. This policy represented a new paradigm to increase knowledge dissemination in universities and research centers in support of innovations in the productive sector (Morais, 2007). Even after the enacting of the Innovation Law, in 2015, data of the PINTEC surveys in 2008, 2010 and 2014 continued similar to those obtained in the PINTEC survey in 2005, showing low levels of cooperation between enterprises and universities or research institutes (few enterprises reported high importance to this fact). Then, the question is: one of the main efforts of the Innovation Law of 2005 was the establishment of an environment conducive to strategic partnerships between universities, technological institutes and companies; therefore, why has this effort not had the desired effect yet, even after 12 years after the law was enacted?

Regarding results on incentives for innovation, Figure 5 shows that the number of companies that have implemented innovation with governmental support has increased in recent years. The proportion of companies that innovated and received governmental support increased from $16.9 \%$ in 2000 PINTEC survey to $40.4 \%$ in 2014 PINTEC survey. It is not possible to assess whether there is complementarity or substitution between the use of enterprise's own resources for innovation and governmental support. This analysis is relevant to optimize the allocation of governmental resources and promote innovations that would not be possible otherwise. Figure 6 shows the number of companies that received governmental support, according to instruments to encourage innovation, allowing to

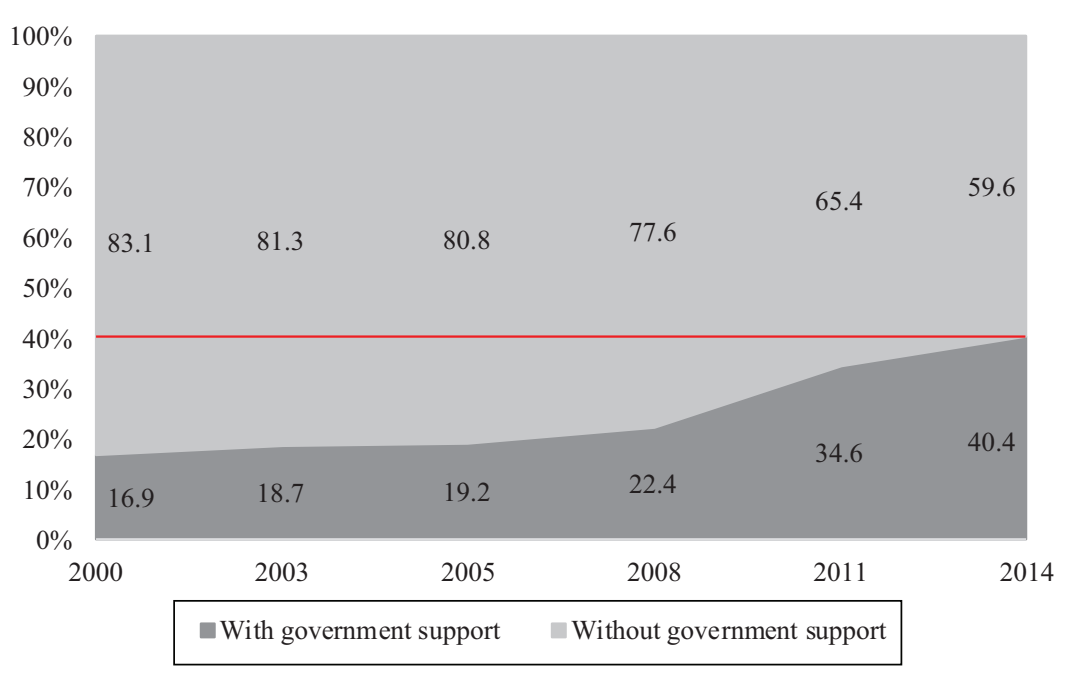

Source: IBGE (2002, 2005, 2007, 2010, 2013, 2016) 


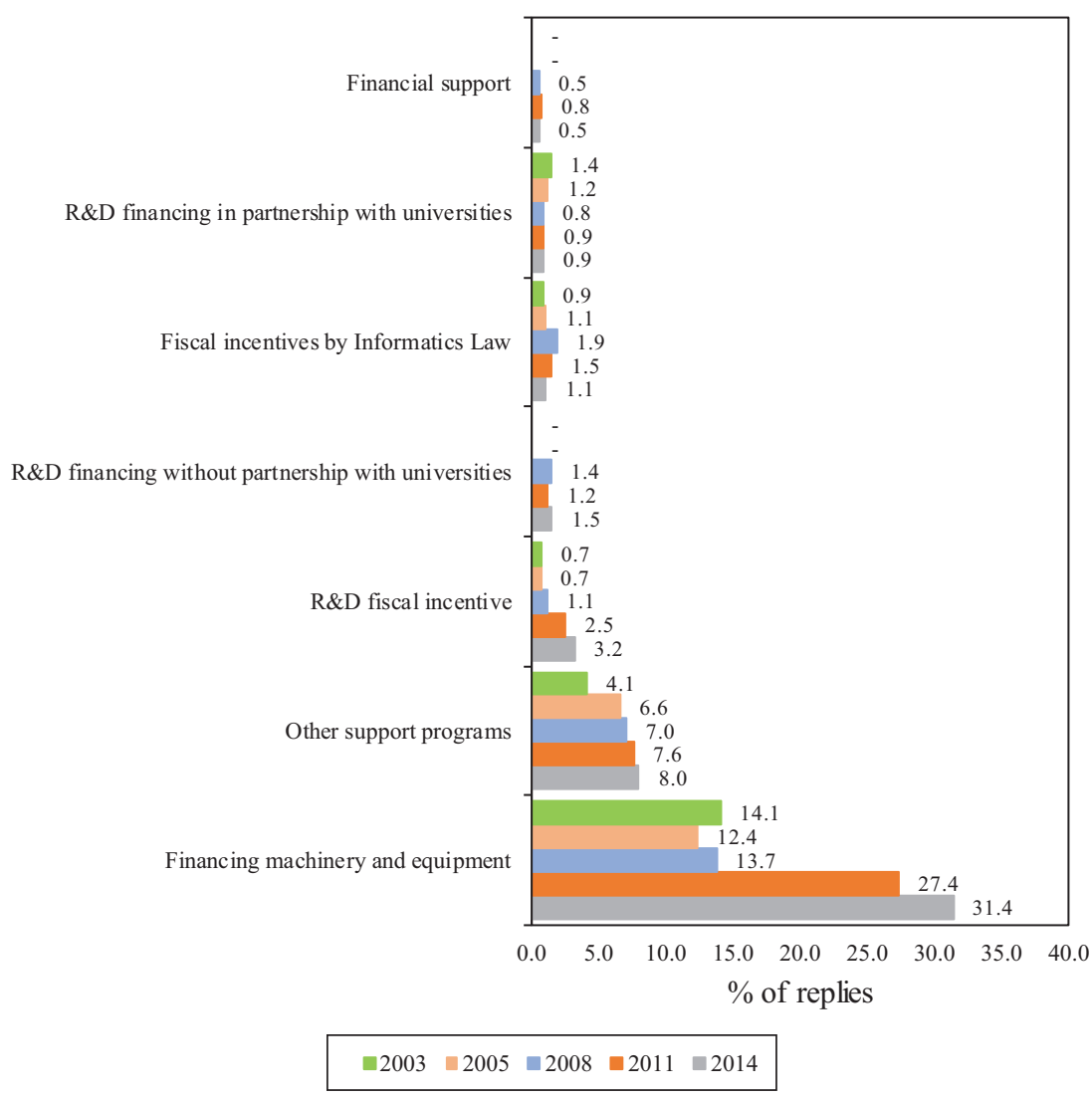

Source: IBGE (2002, 2005, 2007, 2010, 2013, 2016)
Innovation dynamics

159

Figure 6.

Percentage of companies that received governmental support according to instruments to encourage innovation - Brazil

identify which instruments of policies adopted in Brazil were more relevant over time. These results corroborate the analyses presented here. The financing of machinery and equipment is the main form of public support. In developing countries, the government is an important stakeholder to support and finance R\&D, especially in view of the low level of resources that companies allocate to R\&D (OECD, 2005). Therefore, the question is: should the policy of encouraging innovation in Brazil continue prioritizing investments geared toward the acquisition of technology through purchasing machinery and equipment, as they are nonR\&D-based activities, which do not result in new knowledge?

The Brazilian NIS has its financing rooted in its own institutional architecture, a priori, appropriate for adequate functioning of the system (Castro, 2015). However, excessive bureaucracy and controls, as well as time-consuming analyses of funding requests, lack of monitoring after approval and funding hinder access to incentives to innovate (Cirani, Sampaio de Jesus, Esteves, \& de Sousa, 2014), thus compromising the institutional advantage of the financing system for innovation in Brazil.

It is hoped that these results provide subsidies to the public sector and society, highlighting the importance of strategies to intensify and structure the effort for Brazilian 
INMR

18,2

technological development, given the little encouraging scenario of innovation in Brazil. The text raises questions based on solid indicators and comprehensive arguments, which allow obtaining theoretical content analyses and in-depth empirical tests for understanding innovation in Brazil.

\section{Conclusion}

This work presents an exploratory analysis of the Brazilian industrial sector using information from the innovation survey to diagnose the innovation overview in Brazil.

The original tabulations from the PINTEC surveys show that the vast majority of innovations of Brazilian companies refer predominantly to the acquisition of new machinery and equipment. This means that innovation occurs in terms of improvements in production processes rather than in the development or acquisition of new technological skills. This is supported by high investments of companies in Brazil for the acquisition of machinery and equipment and reduced investments in R\&D.

The results showed that most innovations still do not represent a novelty, even to the domestic market. The main interactions in the innovation process do not occur with universities and research institutes that involve R\&D activities, which have contributed to the increased scientific production, as observed by assessing Brazilian scientific production databases. Although innovations to the market generated by Brazilian companies are not numerous, these innovations have higher quality compared to those that are new just for companies, constituting an important tool for Brazilian enterprises to enter new markets.

Another result identified in this study is the profile of access to instruments to encourage innovation, showing that the number of companies that have not received governmental support for innovation is much larger than that of companies that have implemented innovation with governmental support. In addition, financing machinery and equipment is the main form of governmental support, which usually does not generate novelties to the world market.

Several systemic exogenous factors influence innovation dynamics in developing countries, e.g. the uncertainty in the macroeconomic sphere that limits any long-term innovation activity (OECD, 2005). Therefore, institutional stability is important for governmental support concerning innovation instruments, once innovation activities are inherently uncertain, either from an economic or technological perspective, and innovation also refers to long-term investments, especially when compared to purchase and sales.

The analyses presented in this study are preliminary. Further analyses and research on the issues raised in our study could provide explanations and point to paths of public actions for innovation policy, supporting the development of new business strategies.

\section{References}

Abernathy, W. J., \& Utterback, J. M. (1978). Patterns of industrial innovation. Technology Review, 80(7), 40-47.

Ahuja, G., Lampert, C. M., \& Tandon, V. (2008). 1 Moving beyond Schumpeter: Management research on the determinants of technological innovation. Academy of Management Annals, 2(1), 1-98, doi: https://doi.org/10.5465/19416520802211446.

Altenburg, T., Schmitz, H., \& Stamms, A. (2008). Breakthrough? China's and India's transition from production to innovation. World Development, 36(2), 325-344, doi: https://doi.org/10.1016/j. worlddev.2007.06.011.

Barney, J. (1991). Firm resources and sustained competitive advantage. Journal of Management, 17(1), 99-120. doi: https://doi.org/10.1177/014920639101700108. 
Bicen, P., \& Johnson, W. H. (2015). Radical innovation with limited resources in high turbulent markets: The role of lean innovation capability. Creativity and Innovation Management, 24(2), 278-299, doi: https://doi.org/10.1111/caim.12120.

Cassiolato, J. E., Lastres, H. M. M., \& Maciel, M. L. (2003). Systems of innovation and development: evidence from Brazil, Edward Elgar.

Castro, A. C. (2015). Politicas de inovação e capacidades estatais comparadas, Brasil, China e Argentina: Instituto de Pesquisa Econômica Aplicada - IPEA.

Christensen, J. L. Rogaczewska, A. P., \& Vinding, A. L. (1999). Summary report of the focus group on innovative firm networks. pp. 1-19. Retrived From: www.oecd.org/dsti/sti/s_t/inte/nis/archive/ innovative_networks/fg_net2.pdf

Cirani, C. B. S., Sampaio de Jesus, M. A., Esteves, G. B., \& de Sousa, V. J. (2014). Use of policies for innovation in Brazilian enterprises of São Paulo state. Latin American Business Review, 15(1), 45-64, doi: https://doi.org/10.1080/10978526.2014.871216.

Contandriopoulos, A. P., Champagne, F., Potvin, L., Denis, J. L., \& Boyle, P. (1997). Saber preparar uma pesquisa: Definição, estrutura e financiamento, 2nd ed., São Paulo: Abrasco.

Cooper, A. C., \& Schendel, D. (1976). Strategic responses to technological threads. Business Horizons, 19(1). doi: https://doi.org/10.1016/0007-6813(76)90024-0.

Ernst, D. (2008). Innovation offshoring and outsourcing: What are the implications for industrial policy? International Journal of Technological Learning, Innovation and Development, 1(3), 309329, doi: https://doi.org/10.1504/ijtlid.2008.019976.

Filippetti, A., \& Archibugi, D. (2011). Innovation in times of crisis: National systems of innovation, structure, and demand. Research Policy, 40(2), 179-192, doi: https://doi.org/10.1016/j. respol.2010.09.001.

Freeman, C., \& Soete, L. (1997). The economics of industrial innovation, London: Pinter.

Fu, X., Pietrobelli, C., \& Soete, L. (2011). The role of foreign technology and indigenous innovation in the emerging economies: Technological change and catching-up. World Development, 39(7), 1204-1212, doi: https://doi.org/10.1016/j.worlddev.2010.05.009.

Garcia, R., \& Calantone, R. (2002). A critical look at technological innovation typology and innovativeness terminology: A literature review. Journal of Product Innovation Management, 19(2), 110-132, doi: https://doi.org/10.1016/S0737-6782(01)00132-1.

Henderson, R. M., \& Clark, K. B. (1990). Architectural innovation: The reconfiguration of existing product technologies and the failure of established firms. Administrative Science Quarterly, 35(1), 9-30, doi: https://doi.org/10.2307/2393549.

Henderson, R. M., \& Clark, K. B. (2009). Gestão estratégica da tecnologia e da inovação: conceitos e soluções. Capitulo (Vol. 2). Porto Alegre: AMGH.

Hollander, S. (1965). The sources of increased efficiency: A study of Du pont rayon plants, Cambridge, MA: MIT Press.

IBGE (2002). Pesquisa industrial inovação Tecnológica - PINTEC-2000, Rio de Janeiro: IBGE.

IBGE (2005). Pesquisa industrial de inovação Tecnológica - PINTEC-2003, Rio de Janeiro: IBGE.

IBGE (2007). Pesquisa de inovação Tecnológica - PINTEC-2005, Rio de Janeiro: IBGE.

IBGE (2010). Pesquisa de inovação Tecnológica - PINTEC-2008, Rio de Janeiro: IBGE.

IBGE (2013). Pesquisa de inovaçao Tecnológica - PINTEC - 2011, Rio de Janeiro: IBGE.

IBGE (2016). Pesquisa de Inovação - PINTEC-2014, Rio de Janeiro: IBGE.

Jägle, A. (1999). Shareholder value, real options, and innovation in technology-intensive companies. R\&D Management, 29(3), 271-287, doi: https://doi.org/10.1111/1467-9310.00136.

Kim, L. (1997). Imitation to innovation: The dynamics of Korea's technological learning, Harvard Business School Press. 
INMR 18,2

Kiss, A. N., Danis, W. M., \& Cavusgil, S. T. (2012). International entrepreneurship research in emerging economies: A critical review and research agenda. Journal of Business Venturing, 27(2), 266-290, doi: https://doi.org/10.1016/j.jbusvent.2011.09.004.

Kogut, B., \& Zander, U. (1992). Knowledge of the firm, combinative capabilities, and the replication of technology. Organization Science, 3(3), 383-397, doi: https://doi.org/10.2307/2635279.

Lander, B., \& Thorsteinsdóttir, H. (2011). Developing biomedical innovation capacity in India. Science and Public Policy, 38(10), 767-781, doi: https://doi.org/10.1093/spp/38.10.767.

Law $\mathrm{N}^{\circ}$ doi: 10.973. (2004). Provides incentives for innovation and scientific and technological research. Retrieved From: www.planalto.gov.br/ccivil_03/_ato2004-2006/2004/lei/110.973.htm

Lawson, B., \& Samson, D. (2001). Developing innovation capability in organisations: A dynamic capabilities approach. International Journal of Innovation Management, 5(3), 377-400, doi: https://doi.org/10.1142/S1363919601000427.

Lee, K. (2013). Schumpeterian analysis of economic catch-up: Knowledge, Path-Creation, and the MiddleIncome trap, Cambridge University Press.

Lee, K., \& Lim, C. (2001). Technological regimes, catching-up and leapfrogging: Findings from the Korean industries. Research Policy, 30(3), 459-483, doi: https://doi.org/10.1016/S0048-7333(00) 00088-3.

Leifer, R., McDermott, C. M., O'connor, G. C., Peters, L. S., Rice, M. P., \& Veryzer, R. W. Jr, (2000). Radical innovation: How mature companies can outsmart upstarts, Harvard Business Press.

Lema, R., Quadros, R., \& Schmitz, H. (2015). Reorganising global value chains and building innovation capabilities in Brazil and India. Research Policy, 44(7), 1376-1386, doi: https://doi.org/10.1016/j. respol.2015.03.005.

Li, J., \& Kozhekode, R. K. (2009). Developing new innovation models: Shifts in the innovation landscapes in emerging economies and implications for global R\&D management. Journal of International Management, 15(3), 328-339, doi: https://doi.org/10.1016/j.intman.2008.12.005.

Lima, J. C. C. O., Migon, M. N., \& Gomes, S. B. V. (2009). Cadeia produtiva aeronáutica brasileira: Oportunidades e desafios, Rio de Janeiro: Senac Rio.

Lin, J. Y. (2012). From flying geese to leading dragons: New opportunities and strategies for structural transformation in developing countries. Global Policy, 3(4), 397-409, doi: https://doi.org/10.1111/ j.1758-5899.2012.00172.x.

Lundvall, B. A. (2016). Innovation as an interactive process: From user-producer interaction to the national systems of innovation. The learning economy and the economics of hope (pp. 61-83). New York, NY: Anthem Press.

Martins, E. C., \& Terblanche, F. (2003). Building organisational culture that stimulates creativity and innovation. European Journal of Innovation Management, 6(1), 64-74, doi: https://doi.org/ 10.1108/14601060310456337.

Mazzucato, M., \& Penna, C. (2016). The Brazilian innovation system: A mission-oriented policy proposal, Brasília: Centro de Gestão e Estudos Estratégicos. Retrieved From: www.cgee.org.br/thebrazilian-innovation-system $\% 5 \mathrm{Cn}$

Min, S., Kalwani, M. U., \& Robinson, W. T. (2006). Market pioneer and early follower survival risks: A contingency analysis of really new versus incrementally new product-markets. Journal of Marketing, 70(1), 15-33, doi: https://doi.org/10.1509/jmkg.2006.70.1.15.

Morais, J. M. (2007). Politicas de apoio financeiro à inovaçao tecnológica: Avaliação dos programas met/ finep Para empresas de pequeno porte, Instituto de Pesquisa Econômica Aplicada - IPEA.

Nelson, R. R. (1993). National innovation systems: A comparative analysis, New York, NY: Oxford University Press.

Neson, R. R., \& Winter, S. G. (1982). An evolutionary theory of economic change, Cambridge, MA: Belknap Press of Harvard University Press. 
OECD (1999). Boosting innovation the cluster approach, Paris: OECD Publications Service.

OECD (2005). The measurement of scientific and technological activities. Proposes guidelines for collecting and interpreting innovation data, Paris: OECD Publishing.

OECD (2018). Oslo manual 2018. Guidelines for collecting, reporting and using data on innovation, Paris: OECD Publishing. doi: https://doi.org/10.1787/9789264304604-en.

Perrez, C., \& Soete, L. (1988). Catching up in technology: entry barriers and windows. Technical change and economic theory, pp. 458-479. London: Pinter.

Primi, A. (2014). Promoting innovation in Latin America, Maastricht: Datawyse | Universitaire Pers Maastricht.

Radosevic, S., \& Yoruk, E. (2016). Why do we need a theory and metrics of technology upgrading? Asian Journal of Technology Innovation, 24(sup1), 8-32, doi: https://oi.org/10.1080/ 19761597.2016.1207415.

Schumpeter, J. A. (1934). The theory of economic development; an inquiry into profits, capital, credit, interest, and the business cycle, Transaction Publishers.

Swink, M. (2006). Building collaborative innovation capability. Research-Technology Management, 49(2), 37-47, doi: https://doi.org/10.1080/08956308.2006.11657367.

Teece, D., Pisano, G., \& Shuen, A. (1997). Dynamic capabilities and strategic management. Strategic Management Journal, 18(7), 509-533, doi: https://doi.org/10.1002/(SICI)1097-0266(199708) 18:7<509::AID-SMJ882>3.0.CO;2-Z.

The World Bank Group. (2015). Indicators. Foreign direct investment, net inflows (BoP, current US\$). Retrieved from https://data.worldbank.org/indicator/BX.KLT.DINV.CD.WD?locations=ZJ-1WBR

Tushman, M. L., \& Anderson, P. (1986). Technological discontinuities and organizational environments. Administrative Science Quarterly, 31(3), 439-465, doi: https://doi.org/10.2307/ 2392832.

Wade, R. H. (2012). Return of industrial policy? International Review of Applied Economics, 26(2), 223-239, doi: https://doi.org/10.1080/02692171.2011.640312.

Wang, F., Fu, X., \& Chen, J. (2014). Differential forms of technological change and catch-up: Evidence from China. International Journal of Innovation and Technology Management, 11(02), 14500131-1450013-25, doi: https://doi.org/10.1142/S0219877014500138.

Wernerfelt, B. (1984). A resource based view of the firm. Strategic Management Journal, 5(2), 171-180. doi: https://doi.org/10.1002/smj.4250050207.

Zucoloto, G. F., \& Nogueira, M. O. (2016). A dinâmica inovativa das empresas de pequeno porte no brasil, Instituto de Pesquisa Econômica Aplicada - IPEA.

\section{Corresponding author}

Claudia Brito Silva Cirani can be contacted at: claudiabscirani@gmail.com

For instructions on how to order reprints of this article, please visit our website: 